\title{
Effect of Potassium Fertilizer, Solubilizing Bacteria and Sulphur on Yield, Bulb Quality, Storability and Black Mould Disease of Onion
}

\author{
Fawaz, S.B.M. ${ }^{1}$ and Shaima H.F. Abo Zaed ${ }^{2}$ \\ ${ }^{1}$ Plant Pathol. Res. Inst., Agric. Res. Center, Giza, Egypt \\ ${ }^{2}$ Soils, Water and Environ. Res. Inst., Agric. Res. Center, Giza, Egypt
}

Received on: $22 / 8 / 2020$

Accepted for publication on: $11 / 11 / 2020$

\section{Abstract}

This work was conducted to study the influence of potassium fertilizer, solubilizing bacteria (Bacillus circulans) and sulphur on yield, bulb quality, storability and black mould disease of onion. The study revealed that application of feldspar, Bacillus circulans and sulphur fertilizer was the best treatment, where it recorded the higher values of the total count of Bacillus circulans (CFU x $10^{6} / \mathrm{g}$ soil), dehydrogenase enzyme activity in the rhizosphere of onion plants cultivated in soil, plant height $(\mathrm{cm})$, fresh weight (ton fed $^{-1}$ ) and yield (ton fed. ${ }^{-1}$ ) of onion, highest values of total soluble solids (TSS), nitrogen, phosphorus and potassium contents, as well as the lowest values of weight loss percentage of onion bulb and black mold percent during the storage period for 6 months in the both seasons, this treatments would be suitable for productivity, quality and storability for onion production cv. Giza 6 in Egypt under experimental conditions.

\section{Keywords: Onion, fertilizer, potassium solubilizing bacteria, black mold disease.}

\section{Introduction}

(Allium cepa L.) is one of the most important commercial vegetable crops in the world including Egypt (Hussein et al., 2014). It is used throughout the year in the form of salad and for cooking with other vegetables, as well as it has several medical uses (Gupta et al., 2012). Onion is highly valued as both flavoring agent and storing plant material for about eight to ten months (Kumar et al., 2015 and Samuel and Ifeanyi, 2015). The cultivated area in Egypt was 196968 fed., in 2014/2015 season, produced 2,888,791 tons/fed., with an average of 14.67 tons/fed., as mentioned by the (Anonymous, 2001).

Potassium plays key role in onion production. Generally a heavy dose of fertilizer is recommended for onion cultivation, onion is very responsive to potassium. The essential role of potassium in numerous physiological and biochemical proc- esses in the plant including photosynthesis, enhancing the translocation of assimilates, protein synthesis, maintenance of water balance and promoting enzyme activities are well established (Marschner 1995) Among the various nutrients required to produce high yield, potassium deficiency dramatically reduced leaf area and dry matter accumulation and affected assimilate partitioning among plant tissues (Zhao et al., 2001). Sindhu et al., (2010) reported that potassium solubilizing bacteria (KSB), when used as bio fertilizer for agriculture, can reduce the use of application of chemical fertilizer and support ecofriendly crop production. Potassium solubilizing bacteria (KSB) dissolve potassium from insoluble $\mathrm{K}$ bearing minerals such as micas, ilite and orthoclase by excreting organic acids which either directly dissolved rock $\mathrm{K}$ or chelated silicon ions to bring $\mathrm{K}$ into the solution. Sheng, (2005) stated that using KSB led to 
improve the growth of pepper plants. Deepa et al., (2018) found that, the physiological loss in weight, sprouting, rotting and black mould incidence were declined and number of marketable bulbs and TSS of bulb significantly increased during storage with increasing levels of potassium.

Sulphur has been found not only to increase the bulb yield of onion but also improves its quality, especially pungency and flavor (Jaggi and Dixit, 1999). Severe sulphur deficiency during bulb development has detrimental effect on yield and quality of onion (Ajay and Singh, 1994). Sulphur containing secondary compounds are not only important for nutritive value or flavors but also for resistance against pest and diseases (Bell, 1981). Balasubramonian et al., (1979) reported that onion required sulphur fertilization in increasing the production. There are many S-containing compounds, which have been linked, directly or indirectly, with the defenses of plants against microbial pathogens; these include thionins, defensins, glucosinolates, crucifer phytoalexins, alliin, and glutathione (Hell, 1997).

Onion black mold rot disease is the most destructive disease of storages and in the field (Wani and Taskeen, 2011). Rajam, (1992) reported that among the post harvest diseases of onion is black mold rot caused Aspergillus niger which was the predominant one. The pathogen is transmitted by contaminated seed or soil. The infection usually begins at germination of onion seeds and may continue throughout storage (Hayden and Maude, 1992. Hayden et al., 1994a, b; Koycu and Ozer, 1997; and
Sirois et al., 1998). Visual symptoms are not observed on sets developing from seeds infected with pathogen because of latent infection (Ozer and Koycu, 1997) visible external and internal symptoms of black mold occur on infected marketable bulbs (Sumner, 1995; Sinclair and Letham, 1996). Quadri et al., (1982) revealed that the spoilage caused by $A$. niger was as high as $80 \%$. A. niger a soil saprophyte being ubiquitous attacks onion by producing various enzymes and toxins and establishes itself in bulb and other tissues. Bulb rot contributes to $10-50 \%$ of storage losses of different varieties during 3 months storage period under local conditions (Metthananda, 1992). Rahim el al., (1983) reported that in some exotic cultivars, storage loss is even $100 \%$. Onion bulbs are highly susceptible to post-harvest rots, caused by microorganisms particularly fungi during storage period, which have been known to produce toxins caused injurious to human and animal health (Samuel and Ifeanyi, 2015). About $35-40 \%$ of stored onion is lost due to storage diseases. Amongst all Aspergillus spp. (especially $A$. niger) is the most virulent pathogen in the field and storage (Kumar et al., 2015). Post-harvest diseases of onion are due to latent infection from that under field conditions and if these infections are minimized before harvest it is possible to reduce the post-harvest losses (Raju and Naik, 2006). The aim of this work was to study the effect of potassium fertilizer, Bacillus circulans and sulphur on growth, yield and its components, bulb quality as well as bulb storability of onion to improve the qualitative and quanti- 
tative of onion Giza 6 cultivar yield under experimental conditions.

\section{Materials and Methods}

A field experiment was carried out at Mallawi Agriculture Research Station, Minia Governorate, Egypt, during the two successive seasons 2015/2016 and 2016/2017. The experiments were carried out in split plot layout with Randomized Complete Blocks Design (RCBD) with three replicates, The main plot for two levels from sulphur (without or with $100 \mathrm{~kg} \mathrm{fed}^{-1}$ ) and sub plots were allocated levels of potassium fertilizer and bio-fertilizer (Bacillus circulans), no fertilization, bio-fertilizer (Bacillus circulans), potassium sulphate, feldspar, potassium sulphate with bio-fertilization feldspar with bio-fertilization. The growth characters, yield, bulb quality and storability after 2, 4 and 6 months from storage were recorded at room temperature. Each plot was $3.0 \times 3.5 \mathrm{~m}^{2}\left(10.5 \mathrm{~m}^{2}=\right.$ $1 / 400$ feddan). Sixty day-old transplants of onion Giza $6 \mathrm{cv}$ each plot at the recommended spacing $10 \mathrm{~cm}$ on the third week of December. The recommended agricultural practices for onion were used. As ammonium sulphate (N 20.6\%), calcium super phosphate $\left(\mathrm{P}_{2} \mathrm{O}_{5} 15.5 \%\right)$, and potassium sulphate $\left(\mathrm{K}_{2} \mathrm{O} 48 \%\right)$ fertilizers used as sources of nitrogen, phosphorus and potassium, respectively. The recommend amounts of mineral $\mathrm{N}$ and $\mathrm{P}$ fertilizers for onion production were used. The amount of mineral $\mathrm{N}$ fertilizers was splitted into two portions, one half being applied one month after transplants time before the first irrigation and the remaining portion was applied before the second irrigation, 60 days from transplants. While, the amounts of phosphorus and sulphur were added at soil preparation directly. The seedling was dips in bio fertilizes (B.circulans) before transplants. Samples of soils were analyzed using methods cited by (Black et al., 1965). Sampling dates were two weeks before transplants. Some main soil chemical, and fertility characteristics are presented in Table (1):

Some physiochemical analysis of the experimental soil at depth $(0-30 \mathrm{~cm})$ before Plantation in 2015/2016 and 2016/2017 seasons.

\begin{tabular}{|c|c|c|}
\hline Properties & $2015 / 2016$ & $2016 / 2017$ \\
\hline \multicolumn{3}{|l|}{ Physical analysis:- } \\
\hline Sand (\%) & 8.47 & 10.11 \\
\hline Silt (\%) & 54.71 & 49.32 \\
\hline Clay (\%) & 36.82 & 40.57 \\
\hline Soil texture & \multicolumn{2}{|c|}{ Silty clay loam } \\
\hline Mechanical analysis:- & & \\
\hline Organic matter (\%) & 1.60 & 1.72 \\
\hline pH soil - water suspension ratio $(1: 2.5)$ & 8.14 & 8.00 \\
\hline EC $\left(\mathrm{ds} \mathrm{m}^{-1}\right)$ soil - water extract ratio (1:5) & 1.52 & 1.59 \\
\hline \multicolumn{3}{|l|}{ Soluble cations $(\mathrm{meq} / \mathrm{L}):-$} \\
\hline $\mathrm{Ca}^{++}$ & 7.25 & 7.45 \\
\hline $\mathbf{M g}^{++}$ & 2.10 & 2.15 \\
\hline $\mathrm{Na}^{+}$ & 3.20 & 3.22 \\
\hline $\mathbf{K}^{+}$ & 0.18 & 0.20 \\
\hline \multicolumn{3}{|l|}{ Soluble anions $(\mathrm{meq} / \mathrm{L})$ :- } \\
\hline $\mathrm{CO}_{3}{ }^{-}$ & --- & --- \\
\hline $\mathrm{HCO}_{3}^{-}$ & 3.18 & 3.20 \\
\hline $\mathrm{Cl}^{-}$ & 4.15 & 4.10 \\
\hline $\mathrm{SO}_{4}^{-}$ & 5.40 & 5.72 \\
\hline \multicolumn{3}{|l|}{ Available nutrient } \\
\hline Available N \% & 0.19 & 0.18 \\
\hline Available P (ppm) & 16 & 19 \\
\hline Available K (ppm) & 250 & 270 \\
\hline
\end{tabular}




\section{Preparations of Bacillus circulans;}

Bacillus circulans isolate obtained from the microbiology department, Agriculture Research Center, Giza, Egypt. It was inoculated in $250 \mathrm{ml}$ conical flasks that possessed $100 \mathrm{ml}$ Aleksandrov's medium (Zahra, 1969) for 4 week at $28^{\circ} \mathrm{C}$ and then, enriched on nutrient broth medium (Difco, 1984) for 48 hours at $28^{\circ} \mathrm{C}$. Inocula of $B$. circulans $\left(1 \times 10^{8}\right.$ cell $/ \mathrm{ml}$ ) before transplanting the seedlings washed with water and air dried then inoculated by dipping its root system in cell suspension of Bacillus circulans $\left(11 \times 10^{8} \mathrm{cell} / \mathrm{ml}\right)$ for $60 \mathrm{~min}$ before transplanting.

\section{Microbiological determination:}

The plate count method was used to determined $B$. circulans bacteria using Aleksandrov's medium. Plants were harvested $(50 \%$ of the plant leafs turned yellow). Harvest was done at $5^{\text {th }}$ and $10^{\text {th }}$ of May for first and second seasons respectively. A random sample of ten plants from each experimental unit was taken at 150 days after planting and the following data were recorded:

- Plant height $(\mathrm{cm})$.

- Dehydrogenase activity in the rhizosphere of onion plants at 30 and 60 days the bacterial population dynamics in the rhizosphere of the plants and the dehydrogenase activity in the rhizosphere of onion plants was determined according to the method described by Skujins, 1976.

At the appropriate stage of maturity the bulbs in each plot were harvested and then

- Fresh total yield (ton $\mathrm{fed}^{-1}$ )

- Total yield (ton fed ${ }^{-1}$ ) was calculated.

- Total soluble solids percentage (T.S.S. ${ }^{\circ}$ Brix) was determined. Fol- lowing the procedure of Waskar et al., 1999.

- N, P and $\mathrm{K}$ analysis

- Percentage \% black mould disease in bulbs.

- Weight losses percentage $\%$. Concentrations of $\mathrm{N}, \mathrm{P}$, and $\mathrm{K}$ were analyzed from matured bulbs. Five clean sample bulbs from each plot were collected randomly. The bulbs were ground and over dried at $65^{\circ} \mathrm{C}$ for $48 \mathrm{~h}$. The finely ground and dried tissues were wet digested using sulphuric-perchloric acid mixture (1:1) as described by A.O.A.C (2000). Total nitrogen percentage was determined by Kjeldahl method according to Jackson (1967). Total phosphorus percentage was estimated calorimetrically using the chlorostannus-reduce molybdo phosphoric blue color method and measured at the wave length of $640 \mathrm{~nm}$ using spectrophotometer as described by Jackson (1967). Total Potassium percentage was determined using the flame photometer as described by Jackson (1967).

All treated bulbs of each storage treatment collected back in mesh bags to the storage at room temperature (28 \pm 2$)$ five kilogram bulb of each treatment are arranged in randomized complete black design with three replications observation on the black mould of bulbs were recorded at weekly intervals.

\section{Disease assessments.}

By the end of every storage period, bulbs were screened for disease incidence of black mould on regular intervals two, four and six months after storage. Percentages of black mould disease in bulbs were estimated and calculated as follows: 
Lose weigh of bulbs reduction $=(\mathrm{Wz}-$ $\mathrm{Wa} / \mathrm{Wz}) \times 100$

Where $=$

$\mathrm{Wz}=$ Weigh of bulbs at zero time $(5 \mathrm{Kg})$ and

$\mathrm{Wa}=$ Weigh of bulbs after storage

Statistical analysis:

Data collected were subjected to Analysis of Variance (ANOVA) for obtained data in each season was performed. The measured variables were analyzed using MSTATC. Differences among treatments were evaluated by LSD test at 5\% according to procedure out lined by Gomez and Gomez (1984).

\section{Results and Discussion}

Effect of potassium fertilizer, solubilizing bacteria and sulpher on:

1-Total count of $B$. circulans:
The obtained data in Table (2) clearly indicate that potassium fertilizer, Bacillus circulans and sulphur fertilizer populations where the count of $B$. circulans at 30 and 60 days during the two seasons, (4.06 and $15.00 \times 10^{6} \mathrm{CFU} / \mathrm{g}$ and 5.10 and $17.00 \times 10^{6} \mathrm{CFU} / \mathrm{g}$ soil) respectively gave the highest values in total count of B. circulans. The improvement may be as a result of the important role of these microorganisms in improving soil fertility and plant development Bacillus spp. and releasing certain nutrient elements $(\mathrm{P}, \mathrm{Fe}, \mathrm{Zn}$, $\mathrm{Mn}$ and $\mathrm{K}$ ) in addition to contributing with some plant growth substances. These results are in line with those obtained by Abd El-Mageed et.al., (2004) and Massoud et al..( 2009).

Table 2. Effect of potassium fertilizer, $B$. circulans and sulphur on total count of $B$. circulans of onion plants in the two growing seasons.

\begin{tabular}{|l|c|c|c|c|}
\hline \multirow{2}{*}{\multicolumn{1}{|c|}{ Treatments }} & \multicolumn{4}{c|}{$\begin{array}{c}\text { Total count of Bacillus circulans } \\
\text { ( CFU x 10 }\end{array}$} \\
\cline { 2 - 5 } & Season $\mathbf{2 0 1 5}$ /2016 & \multicolumn{2}{c|}{ Season 2016/2017 } \\
\cline { 2 - 5 } & $\mathbf{3 0}$ days & $\mathbf{6 0}$ days & $\mathbf{3 0}$ days & $\mathbf{6 0}$ days \\
\hline no fertilization+ (0) Kg S (control) & 0.21 & 0.29 & 0.21 & 0.33 \\
\hline B. circulans + (0) Kg S & 0.24 & 1.30 & 0.25 & 1.58 \\
\hline K. sulphate + (0) Kg S, & 0.28 & 1.33 & 0.29 & 2.40 \\
\hline Feldspar + (0) Kg S & 0.29 & 1.51 & 0.32 & 0.43 \\
\hline K. sulphate + B. circulans+ (0) Kg S & 0.33 & 2.30 & 0.36 & 2.50 \\
\hline Feldspar + B. circulans + (0) Kg S & 0.26 & 2.90 & 0.39 & 3.50 \\
\hline no fertilization + (100) Kg S & 0.31 & 3.00 & 0.42 & 4.22 \\
\hline B. circulans + (100) Kg S & 0.39 & 4.90 & 0.45 & 5.40 \\
\hline K. sulphat + (100) Kg S, & 1.60 & 5.70 & 1.70 & 5.40 \\
\hline Feldspar + (100) Kg S & 1.21 & 5.00 & 2.00 & 10.00 \\
\hline K. sulphate+ B. circulans + (100) Kg S & 3.50 & 14.0 & 3.50 & 16.00 \\
\hline feldspar + B. circulans + (100) Kg S & 4.06 & 15.0 & 5.10 & 17.00 \\
\hline
\end{tabular}

\section{2- Dehydrogenase Enzyme Activ-} ity:

The results in Table (3) showed application of $100 \mathrm{~kg} \mathrm{~S}^{-1} \mathrm{fe}^{-1}$ gave the higher values of dehydrogenase enzyme activity in the rhizosphere of onion plants cultivated in soil com- pared with zero $\mathrm{kg} \mathrm{S}$ fed $^{-1}$. Data also showed the positive effect of potassium fertilizer and B. circulanson dehydrogenase enzyme activity in the two growing seasons. The highest values on dehydrogenase enzyme activity were recorded in the combined 
treatment feldspar with $B$. circulans at 30days (29.200 and $28.257 \mu \mathrm{g})$, at 60 days, (50.950 and $49.990 \mu \mathrm{g})$ among the other studied treatments in the both seasones compared to control treatment.

Interactions between potassium fertilizer, B. circulans and sulphur fertilizer revered to dehydrogenase enzyme activity in the rhizosphere of onion plants. It could be revealed from the results that application feld- spar, B. circulans compared to control and other treatments. The significantly increase values were 35.600 and $63.800 \quad \mu \mathrm{g}$ TPF (triphenylformasan) at 30 and 60 days during the second season on the other hand, it recorded 34.667 and $62.833 \mu \mathrm{g}$ TPF at 30 and 60 days, respectively during the second season. These results are in line with those obtained by Massoud et al., (2009).

Table 3. Effect of potassium fertilizer, B circulans, sulphur and interactions on dehydrogenase enzyme activity for 30 and 60 days in the rhizosphere of onion plants in two growing seasons.

\begin{tabular}{|c|c|c|c|c|c|}
\hline \multirow{2}{*}{\multicolumn{2}{|c|}{ Treatments }} & \multicolumn{2}{|c|}{ Season 2015/2016 } & \multicolumn{2}{|c|}{ Season 2016/2017 } \\
\hline & & 30 days & 60 days & 30 days & 60 days \\
\hline \multicolumn{6}{|l|}{ Sulphure } \\
\hline \multicolumn{2}{|l|}{ (0) $\mathrm{S}$} & $20.117^{*}$ & 33.067 & 19.158 & 32.147 \\
\hline \multicolumn{2}{|l|}{$100 \mathrm{~K} . \mathrm{g} \mathrm{S}$} & 29.575 & 49.433 & 28.614 & 48.448 \\
\hline \multicolumn{2}{|l|}{ LSD5\% } & 0.175 & 1.656 & 0.202 & 1.851 \\
\hline \multicolumn{6}{|c|}{ Feldspar, K. sulphate and B.circulans } \\
\hline \multicolumn{2}{|l|}{ no fertilization } & 20.075 & 33.075 & 19.068 & 32.030 \\
\hline \multicolumn{2}{|l|}{ Bcirculans } & 20.650 & 36.100 & 19.713 & 35.140 \\
\hline \multicolumn{2}{|l|}{ K. sulphate } & 23.475 & 38.275 & 22.518 & 37.452 \\
\hline \multicolumn{2}{|l|}{ Feldspar } & 27.600 & 41.525 & 26.633 & 40.573 \\
\hline \multicolumn{2}{|l|}{ K. sulphate + B.circulans } & 28.075 & 47.575 & 27.127 & 46.600 \\
\hline \multicolumn{2}{|l|}{ feldspar + B.circulans } & 29.200 & 50.950 & 28.257 & 49.990 \\
\hline \multicolumn{2}{|l|}{ LSD5\% } & 0.157 & 1.697 & 0.186 & 0.980 \\
\hline \multicolumn{6}{|l|}{ Interaction $\mathbf{A} \times \mathbf{B}$} \\
\hline no fertilization & \multirow{6}{*}{$(0) \mathrm{Kg} \mathrm{S}$} & 16.400 & 25.400 & 15.413 & 24.433 \\
\hline B.circulans & & 23.750 & 30.800 & 22.723 & 39.627 \\
\hline \multirow{2}{*}{$\begin{array}{l}\text { K. sulphate } \\
\text { Feldspar }\end{array}$} & & 17.600 & 33.000 & 16.670 & 29.827 \\
\hline & & 23.700 & 34.650 & 22.757 & 40.453 \\
\hline K. sulphate+ B.circulans & & 20.550 & 36.450 & 19.600 & 32.297 \\
\hline feldspar + B.circulans & & 26.400 & 38.100 & 25.437 & 42.607 \\
\hline no fertilization & \multirow{6}{*}{$100 \mathrm{~K} . \mathrm{g} \mathrm{S}$} & 21.700 & 40.750 & 20.733 & 33.697 \\
\hline B.circulans & & 33.500 & 41.400 & 32.533 & 47.450 \\
\hline K. sulphate & & 21.650 & 43.550 & 20.683 & 35.480 \\
\hline Feldspar & & 34.500 & 48.400 & 33.570 & 57.720 \\
\hline \multirow{2}{*}{$\begin{array}{l}\text { K. sulphate+ B.circulans } \\
\text { feldspar + B.circulans }\end{array}$} & & 22.800 & $0 \wedge . \vee \cdots$ & 21.847 & 37.147 \\
\hline & & 35.600 & 63.800 & 34.667 & 62.833 \\
\hline \multicolumn{2}{|l|}{ LSD5\% } & 0.377 & 2.400 & 0.445 & 2.347 \\
\hline
\end{tabular}

*dehydrogenase enzyme activity ( $\mu \mathrm{g}$ TPF) 


\section{3-On plant height, fresh weight and bulb yield:}

Data given in Table (4) show that using of $100 \mathrm{~kg} \mathrm{fed}^{-1}$ of sulphur scored the higher values of plant height $(\mathrm{cm})$, fresh weight (ton fed ${ }^{-1}$ ) and yield (ton fed ${ }^{-1}$ ) of onion compared with zero $\mathrm{kg} \mathrm{fed}^{-1}$. Results also showed that potassium fertilizer and B. circulans had a significant effect on plant height $(\mathrm{cm})$, fresh weight (ton fed ${ }^{-1}$ ) and yield (ton fed ${ }^{-1}$ ) of onion in the two growing seasons. The highest values of plant height (73.067 and $73.633 \mathrm{~cm}$ ), fresh weight (5.683 and 5.767 ton ed $^{-1}$ ) and yield (4.677 and 5.087 ton fed $^{-1}$ ) were recorded in application combined feldspar with $B$. circulans. The lowest values were recorded in control treatment among the other studied treatments in the $1^{\text {st }}$ and $2^{\text {nd }}$ seasons respectively. Interactions between po- tassium fertilizer, B. circulans and sulphur had a significant effect on plant height $(\mathrm{cm})$, fresh weight (ton fed $^{-1}$ ) and yield (ton fed ${ }^{-1}$ ) in the two growing seasons except plant height and fresh weight in the second season. This result might be due to better growth and development of onion plant. This higher photosynthate accumulation in the clove from higher leaves/plant would ensure higher bulbs, large bulb diameter and higher bulb fresh weight, similar results were obtained by Kuldeep et al., (2012) Basma et al., (2018). Onion is an important sulphur-loving crop and sulphur is essentially required for proper growth and yield of crops. Sulphur has been found not only to increase the bulb yield but also improve its quality especially pungency and flavors (Jaggi and Dixit, 1999). 
Table 4. Effect of potassium fertilizer, $B$. circulans, sulphur and interactions on plant height, fresh weight and yield of onion in the two growing seasons.

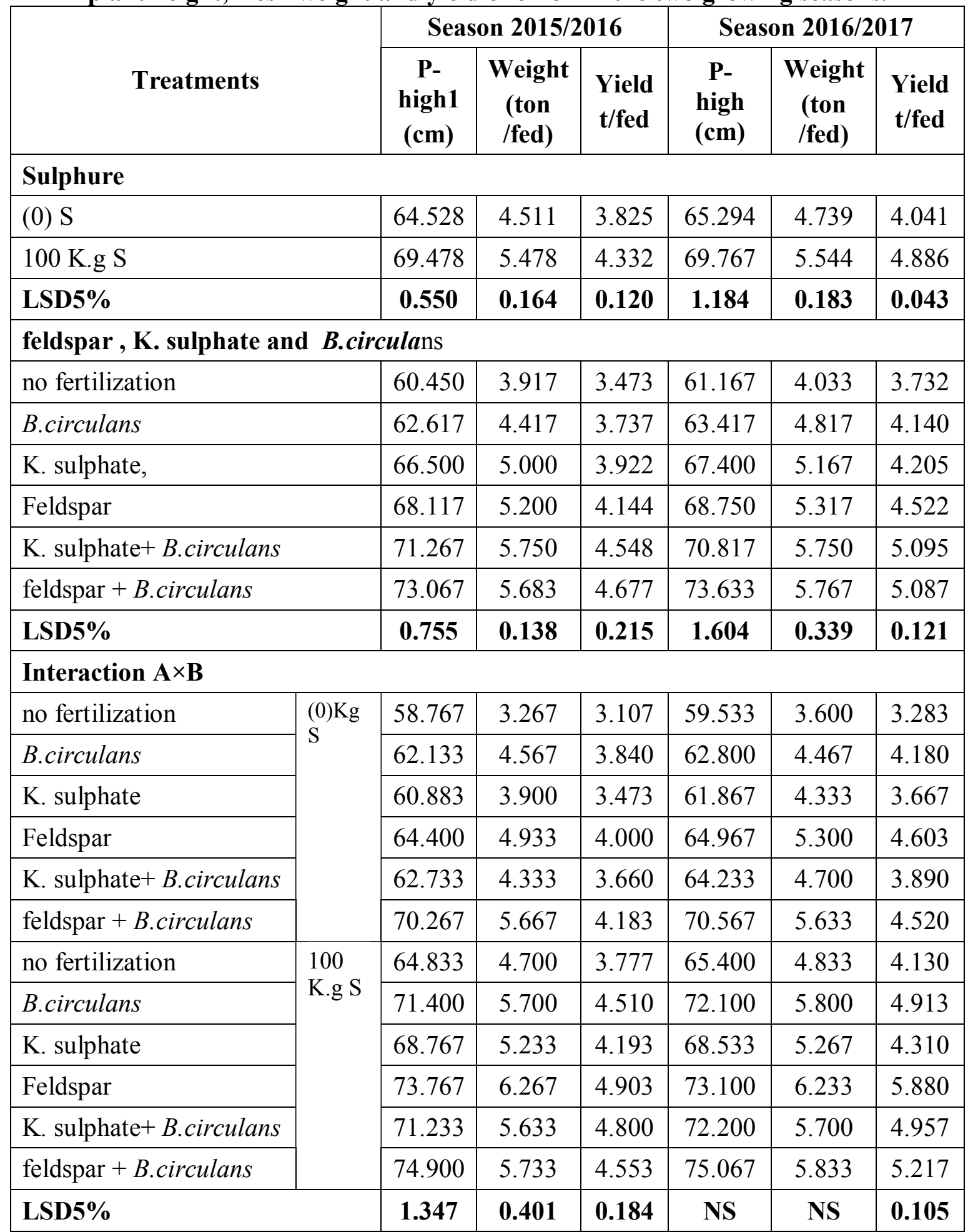

4-On total soluble (TSS), nitrogen, phosphorus and potassium content:

Results in Table (5) Showed that application of $100 \mathrm{~kg} \mathrm{~S}^{-1} \mathrm{fd}^{-1} \mathrm{had}$ the higher values of total soluble solids (TSS), nitrogen, phosphorus and potassium contents of onion compared to application of zero $\mathrm{kg} \mathrm{fed}^{-1}$ 
in the two growing seasons. Onion required sulphur fertilization in increasing the dry matter production. Data in Table (5) indicated that potassium fertilizer and $B$ circulans had a significant effect on total soluble solids (TSS), nitrogen, and phosphorus and potassium contents by onion in the two growing seasons. The highest values on total soluble solids (TSS) (10.607 and $10.592 \%)$, nitrogen (2.185 and $2.188 \%$ ), phosphorus $(0.416$ and $0.417 \%)$ and potassium contents $(0.853$ and $0.858 \%)$ of onion were recorded in application combined feldspar with $B$. circulars. The lowest values of total soluble solids (TSS) (9.503 and 9.638), nitrogen (1.817 and 1.820), phosphorus $(0.370$ and 0.371$)$ and potassium (0.752 and 0.760 ) contents were recorded in control treatment. The obtained results are in accordance with those obtained by Balasubramonian et al., (1979) and Singh and Rathi (1987). Among the various nutrients required to produce high yield, potassium deficiency dramatically reduced leaf area and dry matter accumulation and affected assimilate partitioning among plant tissues (Sindhu et al., 2010). Potassium solubilizing bacteria (KSB) dissolve potassium from insoluble $\mathrm{K}$ bearing minerals such as micas, illite and orthoclase, by excreting organic acids which either directly dissolved rock $\mathrm{K}$ or chelated silicon ions to bring $\mathrm{K}$ into the solution. Sheng (2005) stated that using KSB led to improve the growth of pepper plants.

Data for interactions between of potassium fertilizer, B. circulans and sulphur on total soluble solids (TSS), nitrogen, phosphorus and potassium contents by onion in the two growing seasons. Result cleared that interaction applications had a significant effect on the all previous traits, irrespective of interaction applications with or without sulphur. This result might be due to sulphur has been found not only to increase the bulb yield but also improve its quality especially pungency and flavors (Jaggi and Dixit, 1999). 
Table 5. Effect of potassium fertilizer, B. circulans, sulphur and interactions on total soluble solids (TSS), nitrogen, phosphorus and potassium contents of onion in the two growing seasons.

\begin{tabular}{|c|c|c|c|c|c|c|c|c|c|}
\hline \multirow{2}{*}{\multicolumn{2}{|c|}{ Treatments }} & \multicolumn{4}{|c|}{ Season $2015 / 2016$} & \multicolumn{4}{|c|}{ Season 2016/2017 } \\
\hline & & $\begin{array}{l}\text { T.S.S } \\
(\%)\end{array}$ & $\begin{array}{c}\mathrm{N} \\
(\%)\end{array}$ & $\begin{array}{c}P \\
(\%)\end{array}$ & $\begin{array}{c}\mathbf{K} \\
(\%)\end{array}$ & $\begin{array}{l}\text { T.S.S } \\
(\%)\end{array}$ & $\begin{array}{c} \\
(\%)\end{array}$ & $\begin{array}{c}P \\
(\%)\end{array}$ & $\begin{array}{c}K \\
(\%)\end{array}$ \\
\hline \multicolumn{10}{|l|}{ Sulphure } \\
\hline \multicolumn{2}{|l|}{ (0) $\mathrm{S}$} & 9.827 & 1.926 & 0.386 & 0.777 & 9.807 & 1.932 & 0.387 & 0.783 \\
\hline \multicolumn{2}{|l|}{$100 \mathrm{~K} \cdot g \mathrm{~S}$} & 10.423 & 2.146 & 0.399 & 0.822 & 10.411 & 2.148 & 0.402 & 0.842 \\
\hline \multicolumn{2}{|l|}{ LSD5\% $\%$} & 0.090 & 0.046 & 0.002 & 0.011 & 0.086 & 0.040 & $\mathbf{0 . 0 0 3}$ & 0.011 \\
\hline \multicolumn{10}{|c|}{ Feldspar, K. sulphate and B.circulans } \\
\hline \multicolumn{2}{|c|}{ no fertilization } & 9.503 & 1.817 & 0.370 & 0.752 & 9.638 & 1.8 .20 & 0.371 & 0.760 \\
\hline \multicolumn{2}{|l|}{ B.circulans } & 9.823 & 1.870 & 0.375 & 0.756 & 9.750 & 1.883 & 0.379 & 0.777 \\
\hline \multicolumn{2}{|l|}{ K. sulphate } & 10.040 & 2.055 & 0.385 & 0.770 & 9.993 & 2.057 & 0.387 & 0.798 \\
\hline \multicolumn{2}{|l|}{ Feldspar } & 10.248 & 2.113 & 0.393 & 0.805 & 10.162 & 2.110 & 0.396 & 0.820 \\
\hline \multicolumn{2}{|l|}{ K. sulphate+ B.circulans } & 10.28 & 2.175 & 0.416 & 0.852 & 10.519 & 2.182 & 0.417 & 0.862 \\
\hline \multicolumn{2}{|l|}{ feldspar + B.circulans } & 10.607 & 2.185 & 0.416 & 0.853 & 10.592 & 2.188 & 0.417 & 0.858 \\
\hline \multicolumn{2}{|l|}{ LSD5\% } & 0.171 & 0.019 & 0.004 & 0.014 & 0.141 & 0.019 & 0.006 & 0.019 \\
\hline \multicolumn{10}{|l|}{ Interaction $\mathbf{A} \times \mathbf{B}$} \\
\hline no fertilization & \multirow{6}{*}{$\begin{array}{c}(0) \\
\mathrm{Kg} \\
\mathrm{S}\end{array}$} & 9.207 & 1.697 & 0.360 & 0.737 & 9.397 & 1.710 & 0.361 & 0.740 \\
\hline B.circulans & & 9.800 & 1.937 & 0.381 & 0.767 & 9.880 & 1.930 & 0.381 & 0.780 \\
\hline K. sulphate & & 9.590 & 1.760 & 0.364 & 0.750 & 9.570 & 1.790 & 0.366 & 0.757 \\
\hline feldspar & & 10.057 & 1.980 & 0.386 & 0.780 & 9.930 & 1.997 & 0.392 & 0.797 \\
\hline K.sulphate+ B.circulans & & 9.860 & 1.930 & 0.383 & 0.760 & 9.820 & 1.927 & 0.383 & 0.780 \\
\hline feldspar+ B.circulans & & 10.220 & 2.180 & 0.387 & 0.7 .80 & 10.167 & 2.187 & 0.392 & 0.817 \\
\hline no fertilization & \multirow{7}{*}{$\begin{array}{l}100 \\
\text { K.g } \\
\text { S }\end{array}$} & 9.890 & 2.007 & 0.390 & 0.790 & 9.737 & 2.000 & 0.391 & 0.790 \\
\hline B.circulans & & 10.607 & 2.220 & 0.397 & 0.820 & 10.587 & 2.220 & 0.402 & 0.850 \\
\hline K. sulphat & & 10.087 & 2.050 & 0.405 & 0.797 & 9.991 & 2.057 & 0.403 & 0.807 \\
\hline feldspar & & 10.970 & 2.300 & 0.427 & 0.920 & 11.047 & 2.307 & 0.432 & 0.917 \\
\hline \multirow{2}{*}{ K.sulphate + B.circulans } & & 10.327 & 2.110 & 0.415 & 0.827 & 10.327 & 2.110 & 0.418 & 0.827 \\
\hline & & 10.887 & 2.260 & 0.417 & 0.880 & 10.857 & 2.267 & 0.417 & 0.890 \\
\hline feldspar+ B.circulans & & 10.887 & 2.260 & 0.417 & 0.880 & 10.857 & 2.267 & 0.417 & 0.890 \\
\hline \multicolumn{2}{|l|}{ LSD5\% } & 0.221 & 0.113 & 0.004 & 0.026 & 0.210 & NS & 0.009 & 0.028 \\
\hline
\end{tabular}

\section{5- On storability of onion:}

Results in Table (6) showed that the effect of sulphur fertilizer levels on weight loss (\%) of onion bulb during the storage period for 6 months in the two seasons. Results cleared that sulphur fertilizer levels had a significant effect on weight loss $\%$ of onion bulb during the storage period for 6 months in both seasons. The present results indicated that increasing sulphur fertilizer. Combined with potassium fertilizer and B. circulans had a significant effect on weight loss $\%$ of onion during the storage period for 6 months in the two growing seasons. The lowest values on weight loss \% of onion during the storage period for 6 months by onion were recorded in feldspar with $B$. circulans. The lowest values of weight loss $\%$ of onion bulb during the storage period for two months (3.012 and $2.445 \%$ ), four months (8.990 and 8.768\%) and six months (13.259 and 12.533) among the other studied treatments in the $1^{\text {st }}$ and $2^{\text {nd }}$ seasons respectively. Water loss of onion bulb was lower at higher potassium levels and this relationship is proved to be significant in 
the absence of $\mathrm{N}$ application. These results agree with those mentioned by Deepa et al., (2018).

No significant interactions between potassium fertilizer, B. circulans and sulphur fertilizer with regard to weight loss $\%$ of onion bulb during the storage period for 6 months in the two seasons are shown in Table (4). It could be revealed from the results that application feldspar, B. circulans and sulphur recorded the lowest val- ues of weight loss $\%$ of onion bulb during the storage period for two months except four months in first season and two months in second season. Zaki et al. (2014) referred that there was decrease in bulb weight loss during storage might be due to improve the uptake of both macro and microelements, which positively influenced by biofertilizer with/without sulphur.

Table 6. Effect of potassium fertilizer, B. circulans, sulphur and interactions on weight loss \% of onion bulb during storage period for 6 months of onion in two growing seasons.

\begin{tabular}{|c|c|c|c|c|c|c|c|}
\hline \multirow{2}{*}{\multicolumn{2}{|c|}{ Treatments }} & \multicolumn{3}{|c|}{ Season 2015/2016 } & \multicolumn{3}{|c|}{ Season 2016/2017 } \\
\hline & & $\begin{array}{c}2 \\
\text { months }\end{array}$ & $\begin{array}{c}4 \\
\text { months }\end{array}$ & $\begin{array}{c}6 \\
\text { months }\end{array}$ & $\begin{array}{c}2 \\
\text { months }\end{array}$ & $\begin{array}{c}4 \\
\text { months }\end{array}$ & $\begin{array}{c}6 \\
\text { months }\end{array}$ \\
\hline \multicolumn{8}{|l|}{ Sulphure } \\
\hline \multicolumn{2}{|l|}{ (0) $\mathrm{S}$} & $3.458^{*}$ & 11.354 & 16.118 & 3.027 & 11.376 & 15.573 \\
\hline \multicolumn{2}{|l|}{$100 \mathrm{~K} . \mathrm{g} \mathrm{S}$} & 3.069 & 9.654 & 13.806 & 2.598 & 9.432 & 13.229 \\
\hline \multicolumn{2}{|l|}{ LSD5\% } & 0.124 & $\mathbf{0 . 3 3 5}$ & 0.816 & 0.049 & 0.553 & 0.644 \\
\hline \multicolumn{8}{|c|}{ feldspar, K. sulphate and B.circulans } \\
\hline \multicolumn{2}{|l|}{ no fertilization } & 3.652 & 12.480 & 17.055 & 3.280 & 13.135 & 16.668 \\
\hline \multicolumn{2}{|l|}{ B.circulans } & 3.502 & 11.905 & 16.705 & 3.133 & 11.660 & 15.772 \\
\hline \multicolumn{2}{|l|}{ K. sulphate } & 3.217 & 10.480 & 15.287 & 2.775 & 10.705 & 14.718 \\
\hline \multicolumn{2}{|l|}{ Feldspar } & 3.125 & 10.000 & 14.775 & 2.695 & 9.375 & 14.117 \\
\hline \multicolumn{2}{|c|}{ K. sulphate+ B.circulans } & 3.075 & 9.170 & 12.700 & 2.35 & 8.778 & 12.600 \\
\hline \multicolumn{2}{|c|}{ feldspar + B.circulans } & 3.012 & 8.990 & 13.259 & 2.445 & 8.768 & 12.533 \\
\hline \multicolumn{2}{|l|}{ LSD5\% } & 0.154 & 0.458 & 1.721 & 0.089 & 0.622 & 1.060 \\
\hline \multicolumn{8}{|l|}{ Interaction $\mathbf{A} \times \mathbf{B}$} \\
\hline \multicolumn{2}{|l|}{ no fertilization } & 3.803 & 13.097 & 17.543 & 3.450 & 14.130 & 17.450 \\
\hline \multicolumn{2}{|l|}{ B.circulans } & 3.500 & 11.863 & 16.567 & 3.110 & 12.140 & 15.887 \\
\hline \multicolumn{2}{|l|}{ K. sulphate } & 3.637 & 12.683 & 17.363 & 3.283 & 12.860 & 16.520 \\
\hline \multicolumn{2}{|l|}{$\begin{array}{l}\text { Feldspar } \\
K\end{array}$} & 3.367 & 11.127 & 16.047 & 2.983 & 10.640 & 15.023 \\
\hline $\begin{array}{l}\text { K. sulphate }+ \\
\text { B.circulans }\end{array}$ & ) Kg S & 3.510 & 11.943 & 16.733 & 3.133 & 12.493 & 16.070 \\
\hline $\begin{array}{l}\text { feldspar } \\
\text { B.circulans }\end{array}$ & & 2.923 & 9.017 & 13.840 & 2.417 & 8.917 & 13.367 \\
\hline \multirow{2}{*}{$\begin{array}{l}\text { no fertilization } \\
\text { B.circulans }\end{array}$} & & 3.363 & 11.183 & 16.333 & 2.980 & 10.000 & 15.467 \\
\hline & & 2.887 & 8.817 & 13.217 & 2.410 & 8.750 & 12.767 \\
\hline K. sulphate & & 3.293 & 9.840 & 14.500 & 2.763 & 9.590 & 14.200 \\
\hline Feldspar & 10 & 2.883 & 8.600 & 12.267 & 2.360 & 8,357 & 11.333 \\
\hline $\begin{array}{l}\text { K. sulphate }+ \\
\text { B.circulans }\end{array}$ & $100 \mathrm{~N}$ & 3.140 & 9.380 & 14.233 & 2.550 & 9.180 & 13.733 \\
\hline $\begin{array}{ll}\text { feldspar } & + \\
\text { B.circulans } & \\
\end{array}$ & & 2.857 & 8.500 & 10.900 & 2.307 & 7.967 & 11.000 \\
\hline \multicolumn{2}{|l|}{ LSD5\% } & Ns & 0.819 & ns & 0.120 & Ns & Ns \\
\hline
\end{tabular}

* Bulb weigh loss $(\%)$ 
6-On onion black mould incidaence:

Results in Table (7) cleared that sulphur fertilizer had a significant effect on black mold \% of onion bulb during the storage period for 6 months in both seasons. The present results indicated that increasing sulphur fertilizer to 100 $\mathrm{kg} \mathrm{S}$ fed $^{-1}$ decreased onion black mold compared to $0 \mathrm{~kg} \mathrm{~S}$ fed $^{1}$. Sulphur containing secondary compounds are not only important for nutritive value or flavors but also for resistance against pest and diseases (Bell, 1981). Results in Table (7) Showed that potassium fertilizer and $B$. circulans significantly decreased onion black mold after two, four and six months under storage conditions compared to untreated controls in two successive seasons (2015/2016 and $2016 / 2017)$. The lowest values on onion black mold \% of onion were obtained during the storage period for 6 months. Potassium sulphate with, bio-fertilizer (B. circulans) and feldspar with B. circulans recorded the lowest values of onion black mold \% of onion bulb during the storage period for two months (4.333, 4.333 and $4.567,3.833 \%$ ), four months (7.667, 7.667 and 10.667, $10.000 \%)$ and six months (14.433 and
15.300) among the other studied treatments in the $1^{\text {st }}$ and $2^{\text {nd }}$ seasons respectively. Potassium is responsible for the activation of nitrate reductase enzyme enhance its quality, shelf life of fruit and vegetables, reduces lodging of crops, enhance winter hardiness and imparts disease. Potassium is one of the three major nutrients taken up by the plant in large quantities and the adequate level of potassium increases crop resistance to various diseases (Dayal, et al. 2010). A significant interactions between $\mathrm{K}$. sulphate, feldspar, B. circulans and sulphur fertilizer with regard to black mold $\%$ of onion bulb during the storage period for 6 months in the two seasons are shown in Table (5). It could be revealed from the results that all treatments recorded the lowest values of black mold \% of onion bulb during the storage period for two (4.000 and 3.600), four (6.667 and $8.000)$ and six months (14.000 and 14.333) compared to control (no fertilization). Black mold \% of onion bulb during the storage period for two (15.167 and 15.500), four (24.333 and 25.333) and six months (28.667 and 30.333) among the other studied treatments in the $1^{\text {st }}$ and $2^{\text {nd }}$ seasons respectively. 
Table 7. Effect of potassium fertilizer, B. circulans, sulphur and interactions on incidence of onion black mold after two, four and six months of storage under natural infection in the two growing seasons.

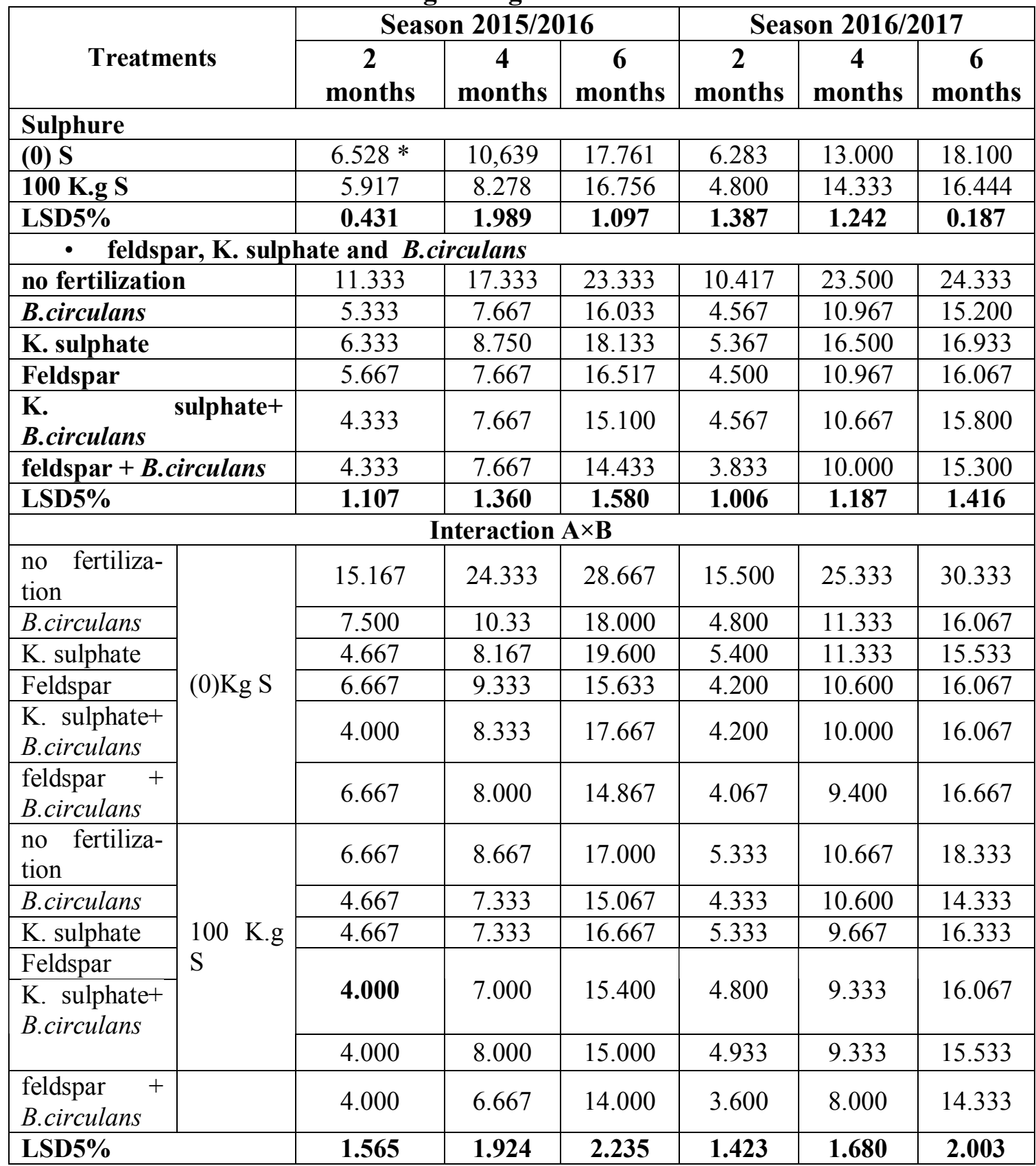

* Black mold (\%)

In conclusion, this study revealed that application of feldspar, B. circulans and sulphur fertilizer gave the higher values of the total count of $B$. circulans dehydrogenises enzyme activity, plant height, fresh weight, bulb yield, total soluble solids (TSS), nitrogen, phosphorus and potassium contents by onion percentages, as well as the lowest values of weight loss percentage and black mold of onion blub during the storage period for 6 months.

\section{References}

Abd El-Mageed, Y.T., Hassan, M.N.M. and Gheeth, R.H.M. (2004). Comparative studies of using chemical 
and biofertilizers on the growth and yield of two snap bean cultivars. Hort. Dept., Fac. Agric., Minia Univ., Egypt.

Ajay, K., Singh, O. (1994). Role of sulphur in nutrient utilizationand catalase activity in onion crop. Indian Journal of Agricultural Research 28, 15-19.

Anonymous, (2001). Annual progress report for Kharif, 1998. Division of Plant Pathology, S.K. University of Agriculture Science and Technology (Kashmir), 34 p.

AOAC International, (2000). Official methods of analysis of AOAC International. Association of Official Analytical Chemists, 2000.

Balasubramonian, A.S., Raman, G.V. and Moorthy, K.K.K.(1979). Effect of sulphur application on the yield and quality of onion (Allium cepa L.). Agric. Res. J. Karala, 17: 138-140.

Basma R. A. Rashwan; Ali, M.A.M. and Ferweez, H. (2018). Growth, yield, bulb quality and storability of Garlic (Allium sativum L.) as affected by using poultry manure, sulphur and different levels of phosphorus fertilizer J. Soil Sci. and Agric. Eng., Mansoura Univ., Vol. 9 (10): 447 - 459.

Bell, A.A. (1981). Biochemical mechanism of disease resistance. Ann. Rev. Plant Physiol. 32: 2 181.

Black, C.A. (1965). Methods of Soil Analysis. Part 2. Chemical and Microbiological Properties. Amer. Soci. Agron., Madison, Wisconsin, USA.

Dayal H, et al. (2010). Effect of nitrogen, phosphorus and zinc on growth and yield of ber cv. Gola under arid and semi-arid conditions. Indian J Hortic.67:277-280.

Deepa, A.H., Wagh, A.P. and Nagre, P.K. (2018). Effect of different doses and splits of potassium on storage of onion. Research \& Reviews: Journal of Ecology and Environmental Sciences, ISSN: 23477830 .

Difco Manual, (1984). Dehydrated culture media and reagents for microbiology. laboratories incorporated Detroit. Michigan, 48232 USS, p: 621.

Gomez, K.A. and Gomez, A.A., (1984). Statistical procedures for agricultural research. $2^{\text {nd }}$ ed. John Wiley and Sons, New York,.

Gupta, R., Khokhar, M.K.and Lal, R. (2012). Management of the black mould disease of Onion. J. Plant Pathol Microb., 3:133.

Hayden, N.J. and Maude, R.B. (1992). The role of seed-borne Aspergillus niger in transmissim of black mould of onion. Plant Patho., 41:573-581.

Hayden, N.J., Maude, R.B., Proctor, F.J. (1994a). Studies on the biology of black mold in (Aspergillus niger) on temperate and tropical onions 1. A comparison of sources of the disease in temperate and tropical field crops, Plant Pathol., 43: 562569.

Hayden, N.J., Maude, R.B. and Proctor, F.J. (1994b). Studies on the biology of black mold (Aspergillus niger) on temperate and tropical onions 2. The effect of treatments on the control of seed- borne A.niger, Plant Ptho., 43: 570-578.

Hell R.(1997). Molecular physiology of plant sulfur metabolism. Planta, 202: 38-148.

Hussein, M., Hassan, M. and AboElyousr, K. (2014). Biological control of Botrytis allii by Trichoderma viride on onion Allium cepa. World Applied Sciences Journal. Vol. 32 (3): 522 -526. 
Jackson, M.L., (1967). Soil Chemical Analysis. Prentice-Hall of India Pvt. Ltd., New Delhi, 498p.

Jaggi, R.C. and Dixit, S.P. (1999). Onion (Allium cepa) responses to sulphur in representative vegetable growing soils of Kangra Valley of HimachalPradesh. Indian J. Agric. Sci., 69: 289-291.

Koycti, N.D. and 0zer, N. (1997). Determination of Seed borne Fungi in Onion and Their.Transmission to Onion Sets Phytoparasitica 25 (1):25-31.

Kuldeep.S., Patel, N., Bhadhauriaand, H. S. and Wankhade, V. R. (2012). Effect of entegrated nutrient management on growth and yield of garlic (Allium sativum L). Adv. Res. J. Crop Improv., 3(2): 164166.

Kumar, V., Sharma, N.S. and Sagar, N.A. (2015). Post harvest management of fungal diseases in onion. A Review. Int. J. Curr. Microbiol. App. Sci., 4(6): 737752.

Marschner H. (1995). Mineral nutrition of higher plants. second edition. 889pp. London: Academic Press, $£ 29.95$ (paperback). D.T. Clarkson

Massoud, O.N., Ebtsam, M. Morsy and Nadia H. El-Batanony (2009). Field response of snap bean (Phaseolus vulgaris L.) To N2fixers bacillus carculans and arbuscular mycorrhizal fungi inoculation through accelerating rock phosphate and feldspar weathering., Australian Journal of Basic and Applied Sciences, 3(2): 844-852.

Metthananda, K.A. (1992). Varietal evaluation for storability of big onion. Seasonal Report, Maha 1991/1992, Agriculture Research Station. Maha Illuppallama. pp. 43-47.
Ozer, N. and Koycu, N.D. (1997). The pathogenicity of Aspergillus niger and some Fusaruim species on onion seed and seedlings. In: Proceedings of the 10 th Congress of the Mediterranean Phatopathology Union, 1-5June 1997, Monpellnier (France), pp 277-281.

Quadri, S.M.H., Srivastava, K.J., Bhonde, S. Pandey, R. U.B. and Bhagchandani, (1982). Fungicidal bioassay against certainimportant pathogens of onion. Pesticides1 6:11-16.

Rahim. M., Husain, A. A. and Siddique, M.A. (1983). Production of bulb and storage ability of three cultivars of onion. Punjab Vegetable Grower 17/18: 13-20.

Rajam, S.R. (1992). Studies on the post harvestfungal spoilage of onion. M. Sc. Ag. Thesis (Unpublished), Tamil NaduAgricultural University, Coimbatore.

Raju K, Nail MK (2006). Effect of preharvest spray of fungicides and botanicals on storage diseases of onion. Indian Phytopath., 59 (2): 133141.

Samuel, O. and Ifeanyi, O. (2015). Fungi associated with the deterioration of post-harvest onion bulbs sold in some markets in Awka, Nigeria. Bioengin.Biosci., 3(5): 90-94.

Sheng, X.F. (2005). Growth promotion and increased potassium uptake of cotton and rape by apotassium releasing strain of Bacillus edaphicus. Soil Biol. and Biochem. 37: 1918-1922.

Sinclair, P.J. and Letham, D.B. (1996). Incidence and sites of visible infection of Aspergillus niger on bulbs of two onion (Allium cepa) cultivars. Australian Plant Pathol., 25: 8-11.

Sindhu, S.S., Dua, S., Verma, M.K. and Khandelwal, A. (2010). Growth promotion of legumes 
byinoculation of rhizosphere bacteria. In: Microbes for legume improvement. Khan, M.S., Zaidi, A. and Musarrat, J., Eds. SpringerWien New York, Germany. pp. 195-235.

Singh, A. and Rathi, K.S. (1987). Effect of planting pattern, nitrogen and sulphur on growth and yield of toria. Indian J. Agron., 32: 450452.

Sirois, K.L., LoParco, D.P. and Lorbeer, J.W.(1998). Development of a bioassay to determine the presence of specified fungal pathogen of onion. In: Proceedings of the Biennial National Onion (and Other Allium) Research Conference, California, 10-12 December 1998, pp. 231-237.

Skujins, J., (1976). Extracellular enzymes in soil. CRC Crit. Rev. Microbiol., 4: 383-421.

Sumner, D.R. (1995). Black mold, In: Schwartz H.F., Mohan, S.K. Eds.), Compendium of Onion and Garlic Diseases. AmericanPhyto- pathology Society Press, Minnesota USA, 26-27.

Wani, A.H. and Taskeen. (2011). Management of black mold rot of onion. Mycopathol., 9: 49-49.

Waskar, D.P., Khedlar, R.M. and Garande, V.K. (1999). Effect of post harvest treatment on shelf life and quality of pomegranate in evaporative cooling chamber and ambient conditions. J. Food Sci. Technol.; 2:114-117.

Zahra, M.K. (1969). Studies on silicate bacteria M.Sc. Thesis, Fac. Agric., Cairo Univ. Egypt. pp.44.7173.101-111.

Zaki, H.E.M., Toney, H.S. and Abd Elraouf, R.M.(2014). Response of two garlic cultivars (Allium sativum L.) to inorganic and organic fertilization. Nature and Science; 12(10): $52-60$.

Zhao, D., Oosterhuis, D. and Bednarz, C. (2001). Influence of Potassium Deficiency on Photosynthesis, Chlorophyll Content, and Chloroplast Ultrastructure of Cotton Plants. Photosynthetica, 39, 103. 
تاثير التسميد البوتاسى و البكتريا المذيبه للبوتاسيوم والكبريت على المحصول وجوده الابصال والقدره التخزينيه ومرض العفن العابون الاسود فى البصل

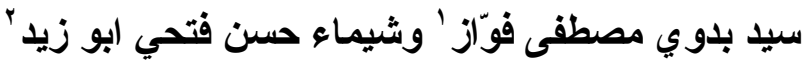

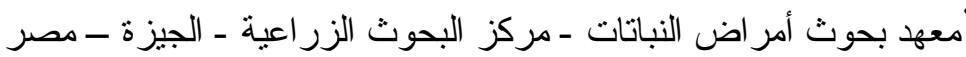

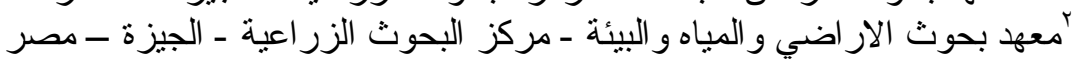

الملخص

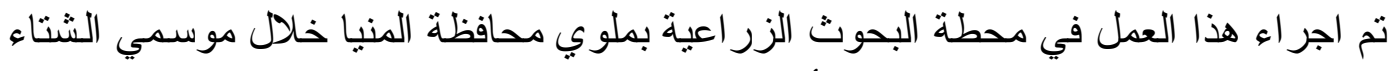

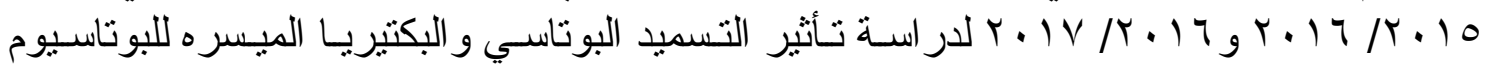

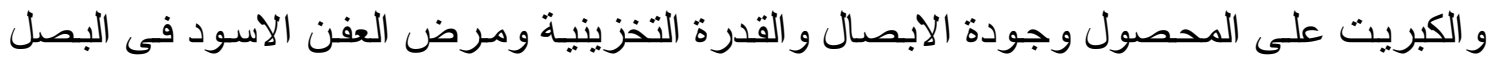

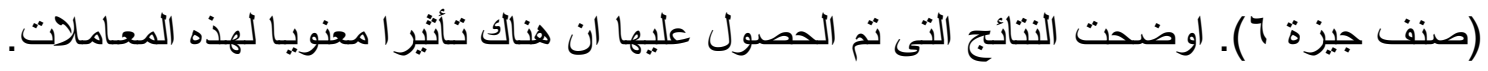

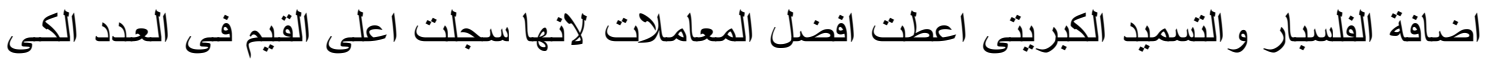

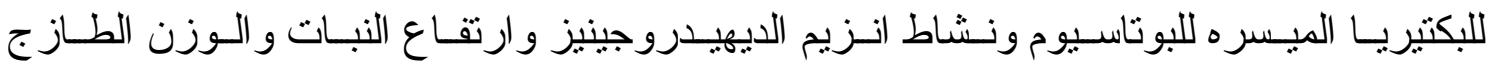

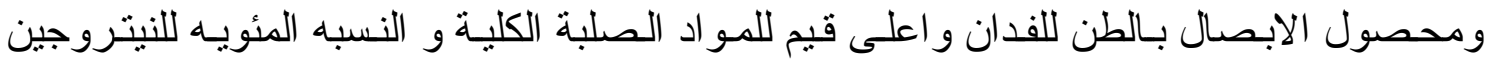

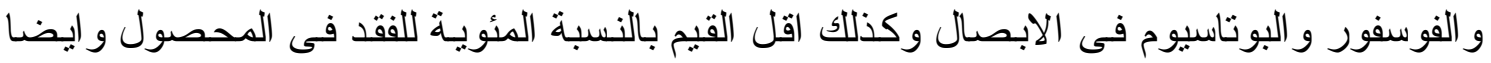

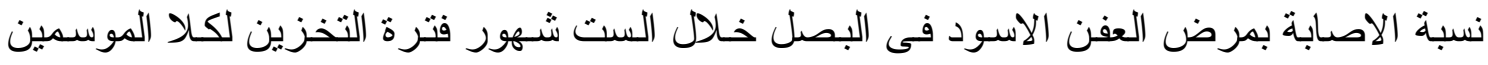

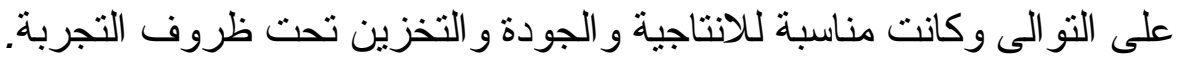

